\title{
A case study of land cover change (1950-2003) and runoff in a Mediterranean catchment
}

\author{
Dennis M. Fox ${ }^{\mathrm{a}, *}$, Emmanuelle Witz ${ }^{\mathrm{a}}$, Violaine Blanc ${ }^{\mathrm{a}}$, Cécile Souliéa ${ }^{\mathrm{a}}$, Marc Penalver-Navarro ${ }^{\mathrm{a}}$, \\ Alain Dervieux ${ }^{\mathrm{b}}$ \\ a UMR 6012 “ESPACE” CNRS, Department of Geography, University of Nice - Sophia Antipolis, BP 3209, 06204 Nice cedex 3, France \\ ${ }^{\mathrm{b}}$ UMR 6012 "ESPACE" CNRS, Equipe DESMID, Université de la Méditerranée, 1 rue Parmentier, 13200 Arles, France
}

Keywords:

Land use

Land cover

Runoff

Channel management

Channel capacity

\begin{abstract}
A B S T R A C T
Mediterranean environments have been subject to major land cover change since the end of the second world war. Housing, agricultural activities, forests, green spaces and other land uses have shifted due to urbanisation and tourism. These changes influence runoff, and municipal authorities often cannot estimate the net impact of complex land cover transitions. During this period, elected representatives have become increasingly sensitive to the risks of flooding and have implemented a number of channel management strategies. The main objective of this case study was to analyse the impact of land cover change on total storm runoff between 1950 and 2003 in a Mediterranean catchment near St Tropez, France. A secondary objective was to compare these changes to the impacts of channel management on bankfull discharge. Aerial photographs were used to classify land cover in 3 urban categories, vineyards and bare soil, forests, and green spaces. Stream discharge was estimated using a distributed event based total runoff approach. After validating the model for a large winter event $(114 \mathrm{~mm})$ for 1982 , runoff was calculated for the same event for 1950 and 2003. Land cover changes occurred mainly in the alluvial plain area. Total gauge catchment urban area increased from 30.1 ha to 393.8 between 1950 and 2003 at the expense mainly of agricultural land, but this was compensated in part by an increase in grassed area. Some of the loss in vineyards was replaced by clearing forested land on the first hills close to the plain. Bank stabilisation and channel maintenance since the 1980's reduced surface roughness and increased channel area, thereby greatly increasing bankfull discharge. While the impact of urbanisation on runoff was small, channel management effects increased bankfull discharge substantially. Flood damage from extreme events was not studied here.
\end{abstract}

(c) 2011 Elsevier Ltd. All rights reserved.

\section{Introduction}

Euro-Mediterranean coastal environments have been subject to rapid land cover change since the end of the Second World War. Urban sprawl along the sea front is the most obvious evolution and several factors account for this: better living standards and greater disposable income, climatic amenities, proximity to the sea and attractive landscapes, and the many historic and cultural interests of the Euro-Mediterranean region. These have combined to attract large numbers of new permanent residents, the building of secondary homes, and the development of a large scale tourism industry. Land cover change in Mediterranean regions is not limited to urban sprawl along the coast (Falcucci, Maiorano, \& Boitani, 2007;). Inland, increased property values have led to the abandonment of low

\footnotetext{
* Corresponding author. Tel.: + 33493375542.

E-mail address: fox@unice.fr (D.M. Fox).
}

revenue agricultural activities, forest expansion, changes in vineyard production, setting aside of agricultural and forest lands in a context of land development speculation, construction of dammed reservoirs... (Bellot, Bonet, Sanchez, \& Chirino, 2001; Delgado, Llorens, Nord, Calder, \& Gallart, 2009; Nunes, de Almeida, \& Coelho, 2011).

Land cover, including forests, agricultural activities, and urban development, is the main control on runoff generation. Runoff coefficient, for example, is highly correlated with watershed imperviousness (Schueler, 1994). The overall impact of land use changes on surface runoff often remains unclear for land managers. Several studies have measured or modelled the impacts of land cover change on catchment hydrology. Some recent examples include those of Burges, Wigmosta, and Meena (1998); Carlson and Arthur (2000); De Roo, Schmuck, Perdigao, and Thielen (2003); Sullivan, Ternan, and Williams (2004); Wu, Hall, and Scatena (2007); Cuo, Lettenmaier, Mattheussen, Storck, and Wiley (2008); Delgado et al. (2009), and these include a range of temporal and 
spatial scales and modelling approches that are too numerous to summarize here. In general, urban development tends to decrease groundwater recharge and wet season base flow and increase storm runoff as the proportion of impervious surface increases (Arnold \& Gibbons, 1996; Konrad \& Booth, 2002). In urban and suburban areas, runoff depends mostly on the percentage of impervious surface area, and peak flows increase with urban development (White \& Greer, 2006). Similar effects have been observed when land use changes from forested to agricultural (Fohrer, Haverkamp, Eckhardt, \& Frede, 2001).

In addition to land cover, other factors can play a role. In Mediterranean forests, soil properties are often correlated with aspect, and $\mathrm{S}$ facing slopes tend to be thinner and stonier than $\mathrm{N}$ facing slopes (Cerdà, Imeson, \& Calvo, 1995; Fox, Maselli, \& Carrega, 2008; Marques \& Mora, 1998; Mouillot, Ratte, Joffre, Mouillot, \& Rambal, 2005; Pausas \& Vallejo, 1999, p. 3). This is due largely to differences in evapotranspiration rates. $\mathrm{S}$ facing slopes have greater incoming direct solar radiation and therefore greater evapotranspiration rates; this leads to lower available moisture, less vegetation, and lower soil organic matter contents in the soil. Chemical weathering is thus less intense and pedogenetic processes are slower, so soils tend to be thinner. In addition, $\mathrm{S}$ facing slopes may be more prone to forest fires since lower soil and vegetation water contents make the vegetation more combustible. One would therefore expect greater runoff from $S$ facing slopes for large rainfall events that saturate the upper soil layer.

Although some steep slopes are cultivated, many agricultural fields are located on flatter land with deeper soils since these are more productive and easier to work. In this case, runoff is determined more by surface characteristics, especially grass cover and soil crusting, than soil depth. Slope angle may also play a secondary role, with greater infiltration on shallower slopes (Fox, Bryan, \& Price, 1996). Unlike vineyards in many other areas of France, Mediterranean vineyards are stripped of their interrow grass cover in the spring to prevent competition for water during the hot dry summer months, and most bare cultivated soils are susceptible to surface crusting. Interrow vegetation cover is left uncontrolled during the winter and varies considerably from one field to another. Infiltration increases with increasing vegetation cover and decreases with surface crust development (Sumner \& Stewart, 1992).

Several studies describe the impacts of land cover change on channel dynamics (Li, Lu, \& Chen, 2007; Mossa \& McLean, 1997; Riedel, Verry, \& Brooks, 2005; Surian \& Rinaldi, 2003). Generally, a geomorphologic approach is used to characterize channel dynamics and morphological evolution. Initial river management studies in applied geomorphology concentrated mainly on reducing flooding risks through civil engineering practises, but these have progressively evolved into more vegetation based methods (Gregory, 2006). Increasingly, the focus has shifted from managing peak discharge in an effort to reduce flooding to broader more ecological and holistic approaches in which discharge, sediment loads, bank stabilisation, water quality, and wildlife habitat concerns are all taken into consideration (Chin, 2006; Gregory, 2006; Gregory, Benito, \& Downs, 2008; Paul \& Meyer, 2001).

River management may affect bankfull discharge by altering channel geometry, resistance to flow, and/or channel bed slope. Engineering, bioengineering, and vegetation techniques such as rock riprap, gabions, coconut fibre, wood planking, or live plantings influence bankfull discharge by their impact on channel roughness. Channel roughness, in turn, influences flow. In addition, bank stabilisation can be accompanied by channel widening which increases the area through which water flows. Bankfull discharge (or channel capacity) is the product of flow velocity and area.

Although several studies have observed increases in runoff with urbanisation or increased cultivation, none of these have related these changes to concurrent changes in river channel management (Burges et al., 1998; Fohrer et al., 2001; Sullivan et al., 2004; White \& Greer, 2006). Except for a few examples where afforestation has reduced runoff (De Roo et al., 2003), land cover studies tend to accentuate the risks of greater discharge. However, increased storm flow with land cover change should not be considered independently from changes in channel capacity resulting from improved river management since this provides a one-sided view which may not reflect the overall change in risk. Elected representatives and land managers have become increasingly sensitive to flooding risks and land cover changes in the past couple of decades have usually been accompanied by changes in river management: channel widening, bank stabilisation, vegetation clearing...

The objective of this case study was to analyse the impacts of land cover change on total storm runoff in a coastal Mediterranean region having undergone rapid land cover change over a period of 53 years (1950-2003) in a context of improved river management. Land cover changes accounted for in this study include changes in forested, vineyards, grassed, and urban areas. In addition, the impact of a dammed reservoir built in the study catchment in 1991 was simulated.

\section{Methods}

\section{Catchment description}

The $234 \mathrm{~km}^{2}$ Giscle catchment is located in SE France near the Gulf of St Tropez (Fig. 1) and is comprised of two topographic units.

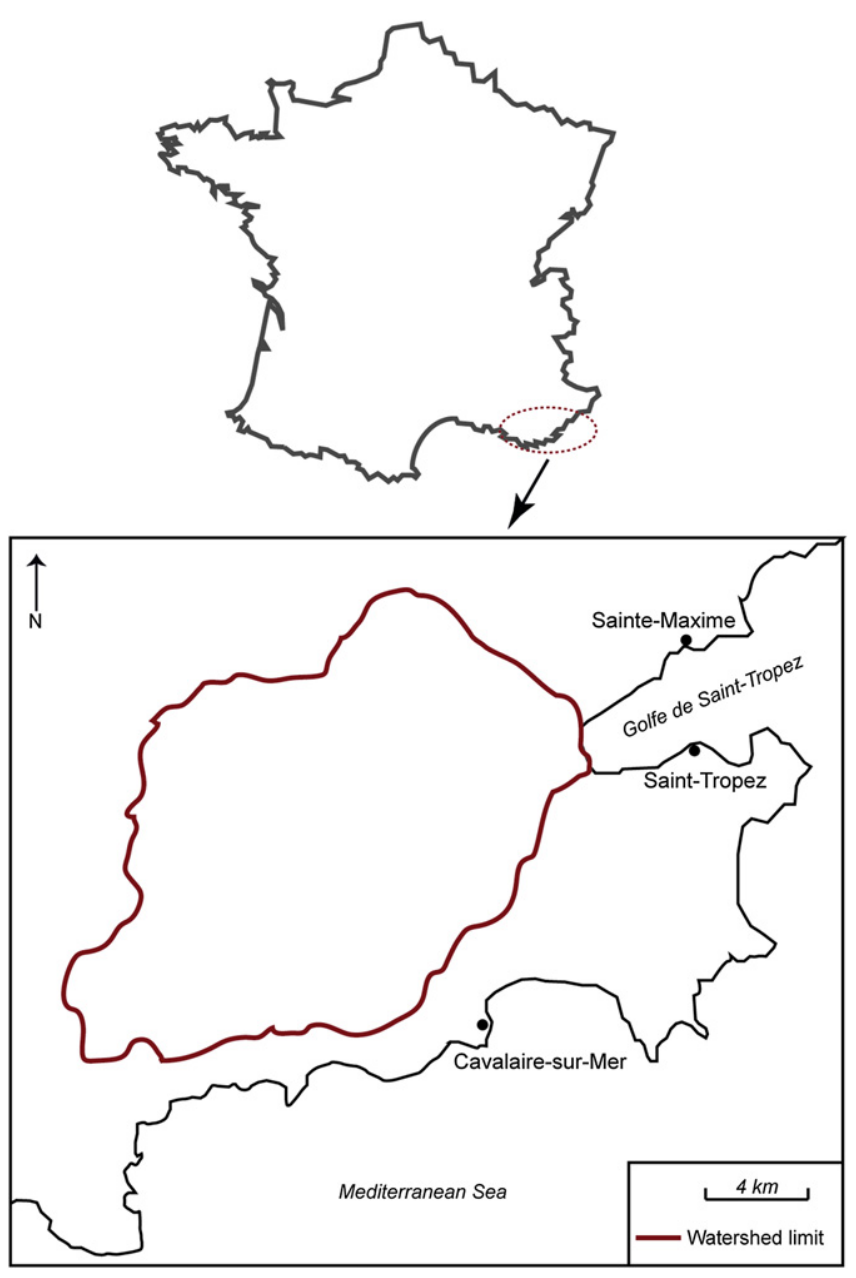

Fig. 1. Catchment location in SE France. 
The hilly upper part of the catchment (about 70\% of catchment) is made up of metamorphic rocks, mostly schist and gneiss. The lower part of the catchment is a gently sloping alluvial plain. Soils throughout the catchment tend to be acid and sandy. Soils formed on the metamorphic substrate vary in surface stoniness and depth, and $\mathrm{S}$ facing slopes tend to be thinner and stonier than $\mathrm{N}$ facing slopes (depth about $20-30 \mathrm{~cm}$ versus $80-90 \mathrm{~cm}$ on $\mathrm{N}$ facing) (Fox et al., 2008). Dominant tree species are Quercus suber (cork oak), Pinus pinaster (pine), and Quercus pubescens. Dominant shrubs are Erica arborea, Phillyrea angoustifolia and latifolia, Arbustus unedo, and Cistus salviaefolius and monspeliensis.

Land cover is strongly influenced by topography. The upland area remains forested because slopes tend to be too steep for agriculture or large scale construction. The alluvial plain is occupied by vineyards, urban areas, and grassed areas. The Verne dam was finished in 1991 and its location is shown in Fig. 2. Storage capacity is $8 \times 10^{6} \mathrm{~m}^{3}$, and its catchment area is $32 \mathrm{~km}^{2}$, representing about $13.7 \%$ of the catchment and $16.1 \%$ of the gauged catchment $\left(198 \mathrm{~km}^{2}\right)$ shown in Fig. 2.

Several tributaries contribute to the Giscle (Fig. 2), but only two of these are of interest to the study in addition to the main Giscle channel because of their size and geographical location within the alluvial plain where most of the urban and vineyard land use types are concentrated. These include the Môle (length $20.5 \mathrm{~km}$, area $81 \mathrm{~km}^{2}$ ), and the Grenouille (length $8.5 \mathrm{~km}$, area $20 \mathrm{~km}^{2}$ ). The Giscle, the Môle and the Grenouille have all been subject to a variety of channel maintenance techniques, as will be described below.

\section{Hydrologic data}

Mean daily discharge is measured automatically about $3.5 \mathrm{~km}$ upstream of the outlet into the Gulf of St Tropez (located in Fig. 2). The stream network displayed in Fig. 2 shows the final stream convergence to occur right at the outlet to the sea. However, the final tributary is channelled into the main channel about $1 \mathrm{~km}$ downstream of the discharge gauge. Since the stream network was derived from a $25 \mathrm{~m}$ Digital Elevation Model (IGN, 2003), it shows a former abandoned natural stream channel. Upslope from the gauge, the DEM derived network and actual network coincide. For this reason, only the gauged catchment was analysed in this study. Total daily rainfall is measured in the plain about $2 \mathrm{~km} \mathrm{~W}$ of the stream gauge (located in Fig. 2). Daily data for both rainfall and discharge were available for a 31 year period, 1975-2005.

Mean annual rainfall for the study period is about $895.3 \mathrm{~mm}$ (std. dev. $=299.8$ ). Peak rainy season is from October to January

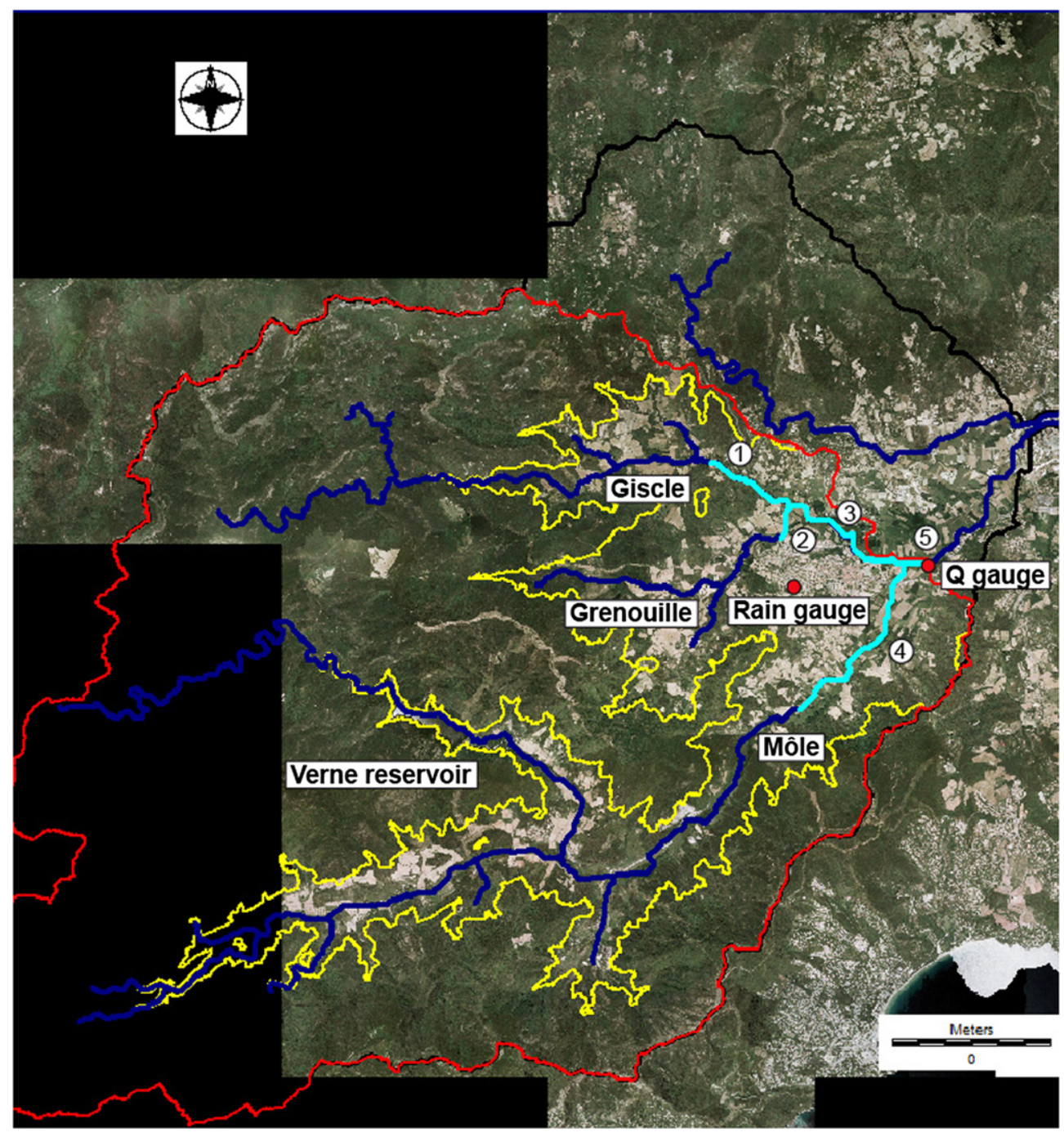

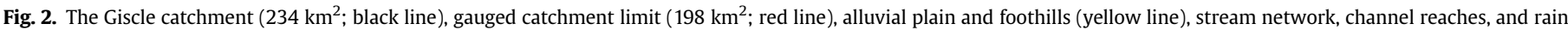
and discharge $(\mathrm{Q})$ gauges are shown. (For interpretation of the references to colour in this figure legend, the reader is referred to the web version of this article.) 
with a second short season occurring in April. (Fig. 3). The dry summer period extends from June to August. Although October is the month with the greatest mean monthly rainfall $(149.3 \mathrm{~mm})$, peak mean monthly discharge $\left(3.4 \mathrm{~m}^{3} \mathrm{~s}^{-1}\right)$ occurs in January due to soil moisture storage recharge in the first months of rainfall after the hot dry summer season. The rainfall-runoff relationship shows a strong seasonal trend where the first heavy rains of September and October generate little channel flow. In contrast, later equivalent winter events create more runoff since antecedent soil moisture is greater.

\section{Land cover mapping}

\section{Aerial photographs}

Aerial photographs are highly suitable for mapping land cover changes for hydrologic purposes for periods up to about 50-60 years (Pauleit, Ennos, \& Golding, 2005; White \& Greer, 2006). Three series of orthorectified aerial photographs were available: 1950 panchromatic, 1982 panchromatic and 2003 colour (orthorectification was carried out by IGN (2003)). Initial cell size for all photos was $0.5 \mathrm{~m}$ but this was increased to $2 \mathrm{~m}$ to make data manipulation easier during digitization. For all three series, about $20 \%$ of the remote western upper part of the catchment was not covered (Fig. 2), but the missing area was entirely forested and underwent insignificant or no land cover changes during the study period.

\section{Land cover classification scheme}

Each series of $2 \mathrm{~m}$ resolution aerial photographs was screen digitized using the following classification: forested, grassed areas, vineyards, urban high density, urban intermediate density, urban low density, and other (water...). Due to the difficulties of classifying complex landscapes with panchromatic images automatically, all land cover categories were decided subjectively based on visual interpretation (Sluiter \& de Jong, 2007). Examples of each of the urban categories are shown in Fig. 4. Isolated houses and buildings were ignored. Although many Mediterranean land use/ land cover change studies include a detailed analysis of changes in vegetation cover (Falcucci et al., 2007; Geri, Amici, \& Rocchini, 2010; Nunes et al., 2011; Pelorosso, Leone, \& Boccia, 2009; Serra, Pons, \& Sauri, 2008; Sluiter \& de Jong, 2007), no attempt was

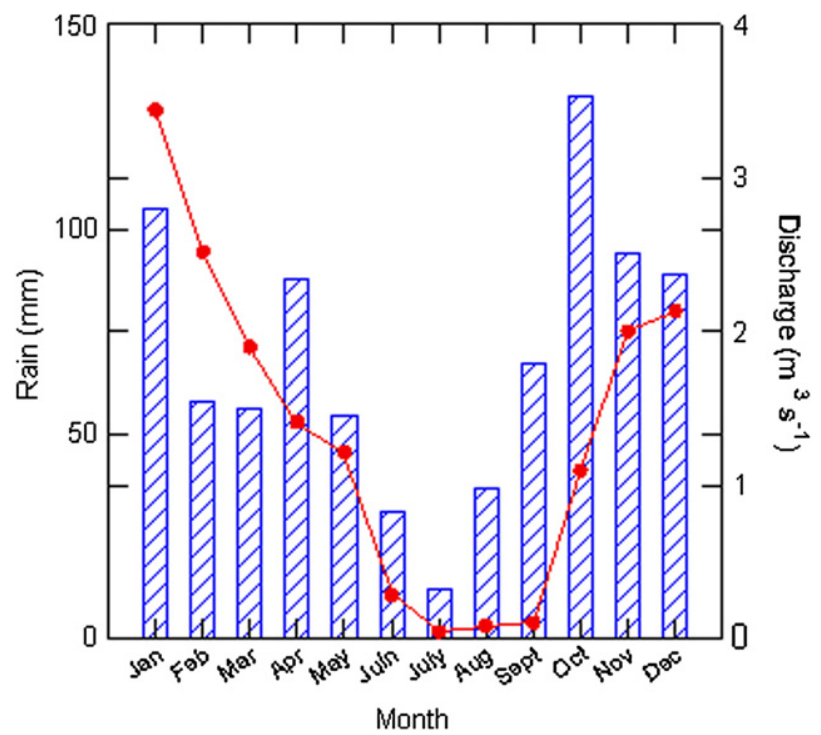

Fig. 3. Monthly rainfall (bars) and discharge (dots) values showing strong seasonal effect as first rains fill soil moisture deficit. made here to distinguish different vegetation types since the main focus of the paper is on runoff dynamics and not land change trends and driving forces. There was insufficient data to link vegetation type to runoff coefficients, and it was considered that spatial variation in runoff within the forest was largely accounted for by slope aspect as described below. The terms "grassed areas" and "prairies" will be used interchangeably, and may include some shrubs and isolated trees. Forest includes both well developed shrublands and trees. Land cover change quantification was carried out using the CROSSTAB module in IDRISI ${ }^{\odot}$ (Eastman, 2010).

Upon completion of land cover mapping using $\operatorname{ArcGIS}^{\odot}$ (ESRI, 2011), digitized polygons were converted to raster format and cell size was changed to $25 \mathrm{~m}$ to make these layers compatible with the $25 \mathrm{~m}$ DEM used for runoff modelling. Data presented in the study correspond to the $25 \mathrm{~m}$ cell resolution. Since most of the land cover changes occurred in or near the alluvial plain, this area was isolated by extracting the surface area beneath an altitude of $100 \mathrm{~m}$. In this way, the plain and adjoining foothills were isolated from the metamorphic highlands. The area of the alluvial plain upstream of the discharge gauge will be referred to as the "alluvial plain and foothills" and it has a surface area of about $56 \mathrm{~km}^{2}$ (roughly $29 \%$ of the gauged catchment) (Fig. 2).

\section{Runoff estimation}

Three modelling approaches were initially considered. The simplest, a rainfall-runoff model (GR4J) (Perrin, Michel, \& Andréassian, 2003) was tested for the study period (Blanc, 2006). Although it clearly showed the impact of the Verne reservoir (built during 1989-1991) on catchment hydrology, the short pre and post dam periods, precipitation and runoff data quality, and high interannual variability made its use inappropriate for detecting the impacts of land cover changes. In general, the high inter-annual variability of the Mediterranean climate (Bellot et al., 2001) make annual based discharge methods difficult to apply since climatic effects can overshadow land cover impacts (Konrad \& Booth, 2002). The most complex approach considered, a fully distributed physically based model coupling hydrologic and hydraulic modules, would have enabled the calculation of the storm hydrograph for selected rainfall events as a function of both land cover change and channel characteristics. However, the extensive database required to run the model and the difficulties in validating it represented a major obstacle in the face of limited resources. Finally, an intermediate solution, an event based, spatially distributed total runoff approach was used. It was decided that if the changes in total storm runoff appeared significant, then a more extensive modelling approach would be justified and tested. This turned out not to be necessary.

Runoff was estimated by first attributing a runoff coefficient to each of the land cover types (Table 1 ) based on bibliographic sources (Bourrier, 2008; Musy \& Higy, 2004; Pauleit \& Duhme, 2000). Although detailed soils data were not available, differences in soil depth and vegetation characteristics for $S$ facing forested slopes in the catchment were sufficiently great to merit distinct values (Fox et al., 2008). Runoff coefficients were then converted into infiltration values (this step is described in detail below) to use in the RUNOFF module of IDRISI ${ }^{\odot}$ (Eastman, 2010). In this raster GIS module, infiltration is subtracted from precipitation for each grid cell and any resulting excess rainfall is channelled to an adjoining downslope cell. Cells therefore can have up to 2 sources of water input, direct rainfall for that cell and runon from the upslope cell, and two types of loss, infiltration and runoff. Spatial heterogeneity in infiltration values within the catchment is fully accounted for since each cell is attributed an infiltration value based on its land use.

In order to estimate the impact of land cover change on runoff, it was necessary to validate the runoff model for one period (1982), 

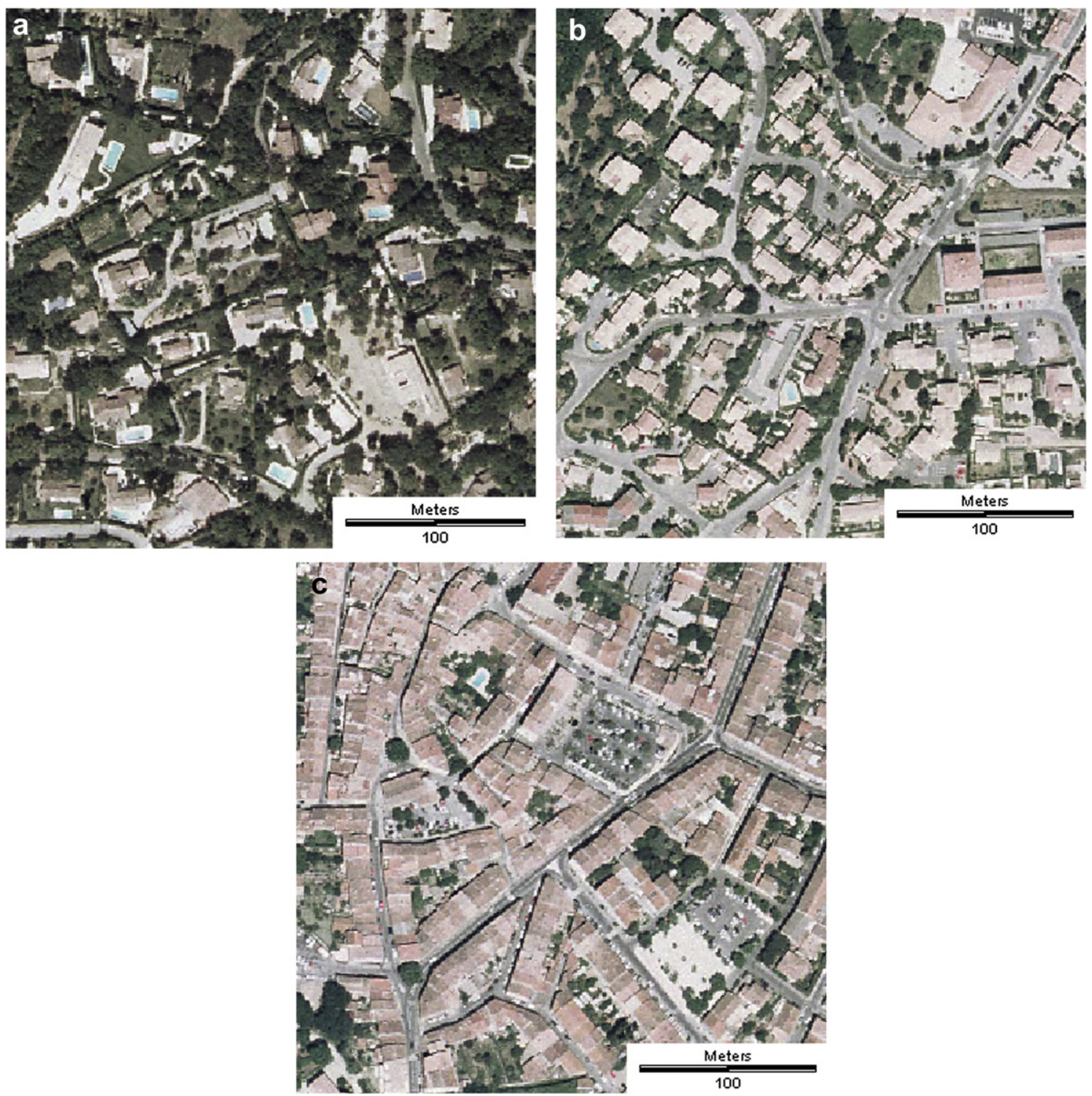

Fig. 4. Examples of low (a), intermediate (b) and high (c) urban densities.

apply the land cover based infiltration values to each of the two other periods (1950 and 2003) and calculate runoff for the same rainfall event (described below), thereby isolating land cover effects from climate differences. Events occurring close to 1982 were selected for this validation step and selection was based on several criteria: mean daily discharge values for the event had to be $\geq$ about $23-25 \mathrm{~m}^{3} \mathrm{~s}^{-1}$, the event had to be separated from the

Table 1

Runoff coefficients and infiltration values for the land cover classes.

\begin{tabular}{lll}
\hline Land cover & Runoff coefficient & anfiltration $(\mathrm{mm})$ \\
\hline Forested, N, E, W facing slopes & 0.20 & 91.6 \\
Forested, S facing slope & 0.40 & 68.7 \\
Vineyards & 0.55 & 51.5 \\
Grassed areas & 0.20 & 91.6 \\
Urban low density & 0.40 & 68.7 \\
Urban intermediate density & 0.70 & 34.4 \\
Urban high density & 0.90 & 11.4 \\
\hline
\end{tabular}

a Infiltration was calculated from runoff coefficient based on a rainfall event of $114.5 \mathrm{~mm}$, as described in text and summarized in Table 2. influence of previous or following large rainfall, it had to have occurred between November and March in order to avoid localized high intensity convective summer storms and the strong seasonal antecedent moisture effect (Burges et al., 1998), the total rainfall for the events had to be similar, and the data had to be free of any apparent errors in either discharge or precipitation. The $23-25 \mathrm{~m}^{3} \mathrm{~s}^{-1}$ range corresponds roughly to the 99th percentile of mean daily discharge values for the period considered; the maximum recorded value for the study year period was $42.7 \mathrm{~m}^{3} \mathrm{~s}^{-1}$, and 41 events had at least one day of mean daily discharge of $23 \mathrm{~m}^{3} \mathrm{~s}^{-1}$ or greater in the 31 year record. It should be noted that maximum daily discharge values are greater than mean daily values but these data were not available. The rainfall-runoff conditions described above sought to isolate typical large winter events occurring around 1982.

In all, 12 events had at least one daily discharge value of $23 \mathrm{~m}^{3} \mathrm{~s}^{-1}$ or greater between 1978 and 1986 (1982 \pm 4 years) and 3 events corresponded to all the criteria described above (Table 2). Mean rainfall for the three events was $114.5 \mathrm{~mm}$ and this value was used to calculate the infiltration values for each land cover type. For 
Table 2

Rainfall events used to validate runoff values for the 1982 land cover period.

\begin{tabular}{|c|c|c|c|c|c|c|}
\hline Date (duration in days) & $\begin{array}{l}\text { Event rainfall } \\
(\mathrm{mm})\end{array}$ & $\begin{array}{l}\text { Event runoff } \\
(\mathrm{mm})\end{array}$ & $\begin{array}{l}\text { Event infiltration } \\
(\mathrm{mm})\end{array}$ & $\begin{array}{l}\text { Event runoff } \\
\text { coefficient }\end{array}$ & $\begin{array}{l}\text { Event peak } \\
\text { discharge }\left(Q_{p}\right)\left(m^{3} s^{-1}\right)\end{array}$ & $\begin{array}{l}\text { Event mean daily } \\
\text { discharge }\left(Q_{m}\right)\left(m^{3} s^{-1}\right)\end{array}$ \\
\hline 8 Feb. $1978-19$ Feb. 1978 (13 days) & 121 & 39.4 & 81.6 & 0.32 & 33.1 & 10.8 \\
\hline 26 December $1981-9$ January 1982 (15 days) & 118.6 & 29.9 & 88.7 & 0.25 & 30.0 & 6.3 \\
\hline 12 Nov. $1984-26$ Nov. 1984 (15 days) & 103.9 & 30.8 & 73.1 & 0.30 & 25.7 & 8.2 \\
\hline MEAN & 114.5 & 33.4 & 81.1 & 0.29 & 29.6 & 8.4 \\
\hline
\end{tabular}

example, a runoff coefficient of 0.20 produces $22.9 \mathrm{~mm}$ of runoff $\left(0.20^{*} 114.5\right)$ and $91.6 \mathrm{~mm}$ of infiltration $(114.5 \mathrm{~mm}-22.9 \mathrm{~mm})$. The three events in Table 2 were used to compare model results to measured discharge data. Since the comparison is based on runoff coefficients and could only be valid for runoff, base flow and throughflow were extracted from the event hydrographs using the method of Roche $(1963,1967)$. In this method, the $\log _{10}$ of discharge is plotted against time for a rainfall event: breaks in the recession limb slope indicate a shift from runoff dominated to throughflow dominated, and from throughflow dominated to base flow dominated conditions, respectively. The method is approximate, especially for large events where flow occurs over several days like the ones considered here. However, it provided an estimation of the storm runoff component in order to determine whether the modelled runoff results were consistent with observed values. Similar values between the modelled runoff and observed events would indicate that the land cover based runoff coefficients and derived infiltration values were realistic and could be applied to all three study periods. Although the runoff method used here does not specifically make use of the USDA-SCS Curve Number, its focus on runoff renders the approach used here similar to spatially distributed Curve Number based methods (Boughton, 1989; Fohrer, Haverkamp, \& Frede, 2004).

\section{Channel characteristics and bankfull discharge}

Channel bed and bank characteristics were mapped on foot during the summer months of 2006 when flow was negligible, and data were integrated into a GIS. Engineering works, vegetation, bank height and channel width and slope were all noted. For this study, only channel lengths within the alluvial plain above the discharge gauge were considered. Channel lengths of interest are shown in Fig. 2. The Giscle was divided into 3 reaches amounting to a cumulative length of $5.1 \mathrm{~km}$ (numbering corresponds to values in Fig. 2): (1) upstream of Grenouille (2200 m), (3) upstream of Môle between the Grenouille and Môle confluences (2300 m), (5) immediately downstream of Môle confluence $(600 \mathrm{~m})$. Channel lengths for the Grenouille (2) and Môle (4) were $700 \mathrm{~m}$ and $4600 \mathrm{~m}$, respectively. All channel segments are shown in Fig. 2. A full record of bank stabilisation types and dates were obtained from local authorities and related to field observations. Data from field mapping were used to define channel width and depth. Bankfull discharge was considered the maximum discharge before bank overflow and was estimated by multiplying the channel surface area by flow velocity. Flow velocity was estimated using the Manning equation, where $\mathrm{V}=\left(\mathrm{R}^{2 / 3} \mathrm{~S}^{0.5}\right) / \mathrm{n}$, and where $\mathrm{V}$ is flow velocity $\left(\mathrm{m} \mathrm{s}^{-1}\right), \mathrm{R}=$ hydraulic radius $\left(\mathrm{m}^{2} \mathrm{~m}^{-1}\right)$, and $\mathrm{n}=$ Manning roughness coefficient (Chow, Maidment, \& Mays, 1988). Manning roughness coefficients ( $n$ ) were estimated using the method described in Arcement and Schneider (1989) based on a protocol developed by Cowan (1956). In the absence of direct field observations for pre-1982 conditions, $n$ values were estimated for an unmaintained natural channel (Table 3).

Pre-1982 channel geometry data were derived from cross sections carried out in 1979 by surveyors. These were used to calculate bankfull discharge prior to channel management strategies. Approximate locations were indicated on maps. Mean bankfull capacity values obtained from cross sections within the reaches defined in Fig. 2 were used for comparison with 2003. Cross sections available for 1979 were the following: 2 for ( 1$), 1$ for (2), 3 for (3), 4 for (4) and 1 for (5). The 2006 cross sections were positioned as closely as possible to the 1979 measurements.

In order to isolate the impact of land cover change on discharge from the effect of the reservoir built in 1991, runoff was first simulated by maintaining a forested land cover in the reservoir catchment for all three periods: 1950, 1982, and 2003 (ie. no dam). Afterwards, discharge was modelled with the reservoir in place and with two scenarios for 2003: (1) the reservoir is not full and all the runoff reaching the reservoir remains behind the dam, (2) the reservoir is full and all the water flowing into it reaches the channel below. This second scenario is the most coherent with a large winter event after several months of rainfall. In the case of a filling reservoir, infiltration rates in the reservoir were set to ensure total infiltration of direct rainfall and runon. In the case of the full reservoir, infiltration rates in the reservoir were set at $0 \mathrm{~mm}$ to ensure runoff propagation through the reservoir and downstream.

\section{Results}

Land cover changes in the catchment can be considered at different scales. In this study, they will be presented for the gauged catchment firstly and the alluvial plain and foothills where most of the changes occurred afterwards. The land cover results will then be followed by a presentation of the 1982 runoff calibration and the runoff simulations for the 5 scenarios described above.

\section{Changes in land cover at the gauged catchment scale}

Changes within the gauged catchment are summarized in the cross tabulation matrices in Tables 4 and 5 . In these tables, the sum of the columns equals the surface area (ha) in the gauged catchment in earlier image; the sum of the rows equals the surface area (ha) in the later image. For example, in Table 4, there were 1591.44 ha in vineyard in 1950 and 1459.31 in 1982. The net change in vineyard surface area was -132.13 ha (last column in Table 4 ). The diagonal shows the persistence of a land use - the surface area (in ha and \%) that underwent no change (Pontius, Shusas, \&

\section{Table 3}

Manning roughness coefficient method and values used for estimating bankfull discharge before 1982 and in 2006 (method from Arcement \& Schneider, 1989).

\begin{tabular}{lllllll}
\hline Channel/period & $\mathrm{n}_{\mathrm{b}}$ & $\mathrm{n}_{1}$ & $\mathrm{n}_{2}$ & $\mathrm{n}_{3}$ & $\mathrm{n}_{4}$ & $\mathrm{n}$ final \\
\hline GISCLE & & & & & & \\
$<1982$ & 0.030 & 0.003 & 0.000 & 0.020 & 0.040 & 0.093 \\
$\begin{array}{l}\text { Co03 } \\
\text { Grenouille }\end{array}$ & 0.030 & 0.003 & 0.000 & 0.002 & 0.002 & 0.037 \\
$<1982$ & & & & & & \\
2003 & 0.026 & 0.003 & 0.000 & 0.020 & 0.045 & 0.094 \\
Mole & 0.026 & 0.003 & 0.000 & 0.002 & 0.002 & 0.033 \\
$<1982$ & & & & & & \\
2003 & 0.026 & 0.003 & 0.000 & 0.020 & 0.050 & 0.099 \\
\hline
\end{tabular}

$\mathrm{n}_{\mathrm{b}}$ : base value of Manning's $\mathrm{n}, \mathrm{n}_{1}$ : bank irregularity, $\mathrm{n}_{2}$ : variation in channel cross section, $\mathrm{n}_{3}$ : obstructions in channel, $\mathrm{n}_{4}$ : vegetation. 
Table 4

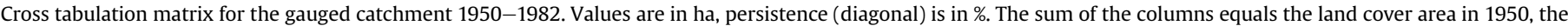
sum of the rows equals land cover area in 1982.

\begin{tabular}{|c|c|c|c|c|c|c|c|c|c|}
\hline \multirow[t]{2}{*}{ TO 1982} & \multicolumn{9}{|l|}{ FROM 1950} \\
\hline & Forest & Vineyards & Prairies & High & Medium & Low & Other & Total 1982 & Change \\
\hline Forest & 17334.75 (97.8) & 229.69 & 140.94 & 0.00 & 0.00 & 0.00 & 0.00 & 17705.38 & -17.00 \\
\hline Vineyards & 282.06 & $1061.81(66.7)$ & 115.44 & 0.00 & 0.00 & 0.00 & 0.00 & 1459.31 & -132.13 \\
\hline Prairies & 73.56 & 210.56 & $222.44(44.4)$ & 0.00 & 0.00 & 0.00 & 0.00 & 506.56 & 5.25 \\
\hline High & 4.50 & 20.69 & 3.94 & $21.06(100.0)$ & 0.00 & 0.44 & 0.00 & 50.63 & 29.56 \\
\hline Medium & 6.56 & 35.56 & 6.69 & 0.00 & 0.00 & 4.94 & 0.00 & 53.75 & 53.75 \\
\hline Low & 19.25 & 33.00 & 11.88 & 0.00 & 0.00 & $3.69(40.7)$ & 0.00 & 67.81 & 58.75 \\
\hline Other & 1.69 & 0.13 & 0.00 & 0.00 & 0.00 & 0.00 & 0.00 & 1.81 & 1.81 \\
\hline Total 1950 & 17722.38 & 1591.44 & 501.31 & 21.06 & 0.00 & 9.06 & 0.00 & 19845.25 & 0.00 \\
\hline
\end{tabular}

McEachern, 2004). For example, 1061.81 ha (or 66.7\%) of the vineyards were classified as vineyard in both 1950 and 1982. "Swapping" is defined as the exchange of land between different land cover types (Pontius et al., 2004); for example, vineyards lost 229.69 ha to forest between 1950 and 1982, but gained 282.06 ha in exchange. The net change was a gain of only 52.41 ha by vineyards.

For all periods, forest occupies the greatest surface area by far (almost 90\% of the gauged catchment). As can be seen in Fig. 2, most of this is concentrated in the upper hilly parts of the catchment. After forest, vineyards and grassed areas occupy the most area. During the 1950-1982 period, the greatest net loss is in vineyards ( $-132.13 \mathrm{ha})$. The greatest net gains are for low, medium and high density urban areas. Most of their gain is from vineyards. Forest has a high persistence (97.8\%), but this is due largely to its great surface area and distance from other land cover types. Vineyards and prairies have much lower persistence than forest, showing their tendency to change land cover. Much of this is in the form of swapping between forest, vineyards, and prairie, so the net change for both prairies and forest is negligible.

Between 1982 and 2003 (Table 5), the greatest loss continues to be experienced by vineyards. The surface area lost is roughly twice the area during 1950-1982, even though the 1982-2003 period is shorter ( 21 yrs vs. 32 yrs). Forest area also decreases substantially. Unlike during 1950-1982, the greatest gain in 1982-2003 is in grassed areas with a net increase of 224.69 ha. The urban land cover types all increased substantially, at a rate greater than twice the pace of change experienced in 1950-1982. In the earlier period, much of the urban growth was at the expense of vineyards; during the 1982-2003 period, urban land covers gained from vineyards, forest and prairies. As for 1950-1982, swapping between forest, vineyards and prairies remained important.

\section{Changes in land cover in the gauged alluvial plain and foothills}

Tables 6 and 7 show cross tabulation matrices for the alluvial plain and foothills. The trends are similar to those revealed in Tables 4 and 5 and require little additional comment. The persistence of forest remains high but has decreased showing that most of the relative changes in forest are concentrated near the alluvial plain. However, forest lost less area within the plain than the catchment as a whole whereas vineyards lost more area. This suggests some of the forest to vineyard compensation was occurring outside the alluvial plain and foothills area delimited by the $100 \mathrm{~m}$ contour. Secondly, about $95 \%$ of the change in the urban covers (high, medium and low) occurred in the alluvial plain and foothills. Hence, outside the alluvial plain and foothills area, there was some swapping between forest, vineyards and prairies, but there was virtually no growth in any of the urban covers.

Fig. $5 a-c$ show that urban growth occurred essentially by expansion of the 1950 village core onto surrounding vineyards in the eastern part of the gauged catchment. Swapping between forest, vineyards and prairie noted above follows a less clearly defined spatial pattern, though there are a few tendencies. Firstly, the growth in grassed areas tends to be concentrated in proximity to the stream network. This can be seen especially in the south central part of Fig. $5 a-c$. Vineyard to prairies conversion was also focussed on lands near the urban area in the eastern part of the gauged catchment (particularly to the north). Compensation for the loss in vineyards (to urban and grassed areas) occurred at some distance from the urban core, and usually at the expense of forest: comparing 1950 (Fig. 5a) to 2003 (Fig. 5c), this can be seen west of the urban core, near the Giscle and Grenouille (Fig. 2), and the extreme western part of the Môle. Finally, the conversion of forest to other that can be seen in Tables 5 and 7 is related mainly to the construction of the dammed reservoir which is present in the air photos of Fig. 2 and land cover map of Fig. 5c.

Fig. 6 summarizes the changes in the gauge alluvial plain and foothills. Units are expressed as a percentage of the gauge alluvial plain and foothills area to facilitate the comprehension of the relative areas involved. As described above, the plain and foothills are dominated by forest and vineyards, but these land covers show a net loss between 1950 and 2003. Grassed areas and the urban categories profited the most from the losses in forest and vineyards, as can be seen in Fig. 6 .

Table 5

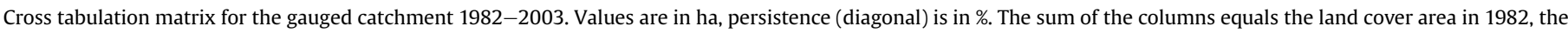
sum of the rows equals land cover area in 2003.

\begin{tabular}{|c|c|c|c|c|c|c|c|c|c|}
\hline \multirow[t]{2}{*}{ TO 2003} & \multicolumn{9}{|l|}{ FROM 1982} \\
\hline & Forest & Vineyards & Prairies & High & Medium & Low & Other & Total 2003 & Change \\
\hline Forest & $17126.50(96.7)$ & 217.50 & 129.19 & 0.00 & 0.00 & 0.00 & 0.00 & 17473.19 & -232.19 \\
\hline Vineyards & 232.94 & $883.25(60.5)$ & 73.19 & 0.00 & 0.00 & 0.00 & 0.00 & 1189.38 & -269.94 \\
\hline Prairies & 222.38 & 262.38 & $246.50(48.7)$ & 0.00 & 0.00 & 0.00 & 0.00 & 731.25 & 224.69 \\
\hline High & 3.50 & 25.19 & 15.50 & $50.63(100.0)$ & 18.31 & 3.75 & 0.00 & 116.88 & 66.25 \\
\hline Medium & 29.06 & 49.38 & 30.06 & 0.00 & $35.44(65.9)$ & 17.19 & 0.00 & 161.13 & 107.38 \\
\hline Low & 35.88 & 21.00 & 12.06 & 0.00 & 0.00 & $46.88(69.1)$ & 0.00 & 115.81 & 48.00 \\
\hline Other & 55.13 & 0.63 & 0.06 & 0.00 & 0.00 & 0.00 & $1.81(100.0)$ & 57.63 & 55.81 \\
\hline Total 1982 & 17705.38 & 1459.31 & 506.56 & 50.63 & 53.75 & 67.81 & 1.81 & 19845.25 & 0.00 \\
\hline
\end{tabular}


Table 6

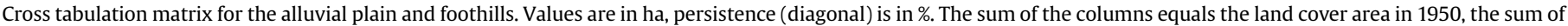
the rows equals land cover area in 1982. plain area expressed in \% of non-forest land cover for the three time periods.

\begin{tabular}{|c|c|c|c|c|c|c|c|c|c|}
\hline \multirow[t]{2}{*}{ TO 1982} & \multicolumn{9}{|l|}{ FROM 1950} \\
\hline & Forest & Vineyards & Prairies & High & Medium & Low & Other & Total 1982 & Change \\
\hline Forest & 3240.81 (91.5) & 210.88 & 116.69 & 0.00 & 0.00 & 0.00 & 0.00 & 3568.38 & 25.06 \\
\hline Vineyards & 223.81 & $1034.31(67.1)$ & 110.44 & 0.00 & 0.00 & 0.00 & 0.00 & 1368.56 & -172.31 \\
\hline Prairies & 53.81 & 206.31 & $212.13(46.0)$ & 0.00 & 0.00 & 0.00 & 0.00 & 472.25 & 11.19 \\
\hline High & 4.50 & 20.69 & 3.75 & $18.69(100.0)$ & 0.00 & 0.13 & 0.00 & 47.75 & 29.06 \\
\hline Medium & 5.88 & 35.56 & 6.69 & 0.00 & 0.00 & 4.94 & 0.00 & 53.06 & 53.06 \\
\hline Low & 12.81 & 33.00 & 11.38 & 0.00 & 0.00 & $3.44(40.4)$ & 0.00 & 60.63 & 52.13 \\
\hline Other & 1.69 & 0.13 & 0.00 & 0.00 & 0.00 & 0.00 & 0.00 & 1.81 & 1.81 \\
\hline Total 1950 & 3543.31 & 1540.88 & 461.06 & 18.69 & 0.00 & 8.50 & 0.00 & 5572.44 & 0.00 \\
\hline
\end{tabular}

Impact of land cover changes on runoff

As shown in Table 2, mean runoff for the three calibration events was $33.4 \mathrm{~mm}$ at the discharge gauge. Using the runoff coefficients in Table 1, runoff for a $114.5 \mathrm{~mm}$ event was $33.3 \mathrm{~mm}$ for 1982 . The runoff coefficient values in Table 1 were therefore considered realistic for simulating event runoff for the purpose of comparing the 3 periods.

Runoff values at the discharge gauge were $33.2 \mathrm{~mm}, 33.3 \mathrm{~mm}$, and $33.7 \mathrm{~mm}$ for the 1950, 1982, and 2003 periods, respectively. Changes in runoff with changes in land cover over the 1950-2003 period were therefore minor, and total runoff increased by less than about $2 \%$. The impact of increased urban development on channel discharge is slightly underestimated since some urban runoff is directed into the river channel through ditches and drainage pipes whereas the runoff model has it flow over other land cover types with greater infiltration values. Mean infiltration within a $50 \mathrm{~m}$ buffer zone around the river channels in the alluvial plain increased from $75.7 \mathrm{~mm}$ in 1950 to $81.0 \mathrm{~mm}$ in 2003. This reflects limited intermediate density urban expansion along the main channel and an important conversion of vineyard to grassed surfaces along stream channels in the plain as described above.

Runoff for the 2003 scenario with the reservoir filling was $28.5 \mathrm{~mm}$, and it was $33.7 \mathrm{~mm}$ for the reservoir full. Trapping of runoff in the reservoir sub-catchment led to a $15 \%$ decrease in runoff. This is roughly proportional to the surface area of the reservoir catchment. The scenario with the reservoir full showed no difference from the natural forested catchment: this too could be expected since the surface area of the non infiltrating reservoir remains negligible at the catchment scale.

\section{Evolution in channel characteristics and impact on bankfull discharge}

Fig. 7 shows the evolution of channel management practises over time in the entire catchment. Although some civil engineering methods were put in place before 1979, these were concentrated mainly near the newly built port area at the channel outlet, well below the gauged catchment. In the 1980's and early 1990's, the focus was on civil engineering techniques which dealt with bank stabilisation and channel widening in the more problematic or strategic reaches of the Giscle channel. Progressively, channel management evolved into less onerous and more ecological bioengineering methods introduced around 2000. These can be found on the Giscle, the Môle and the Grenouille. Table 8 summarizes the lengths of bank treatments for civil and bioenginnering techniques for the channel lengths shown in Fig. 2. Finally, from the late 1990's till present, channel maintenance has become a routine practise throughout the catchment. This includes the clearing of live vegetation in the channel, removal of logs or unstable bank trees, and levelling of the channel bed in cases of large sediment deposits.

The management methods described have all contributed to increasing flow efficiency and improving channel capacity. Surface roughness decreased as live and dead vegetation were cleared from the channels. Bank armouring techniques were systematically accompanied by channel widening, thereby increasing the area through which flow occurs. Table 9 summarizes changes in bankfull discharge for channel lengths considered in the runoff model. Bankfull discharge increased significantly for all channel lengths concerned except the Môle where little change was observed. In this reach, channel clearing effects were countered by an apparent decrease in width between the 1979 and 2006 surveys. This unexpected change could not be verified on the air photos because tree crowns on the river banks hide the channel in all air photos.

\section{Discussion}

A full analysis of the environmental and socio-economic factors that drive land cover change in the gauged catchment, as was performed by De Aranzabal, Schmitz, Aguilera, and Pineda (2008) and Serra et al. (2008) in Mediterranean Spain, is beyond the scope of this study, but some dominant factors can be cited. Topography is first among these. Land cover other than forest and

Table 7

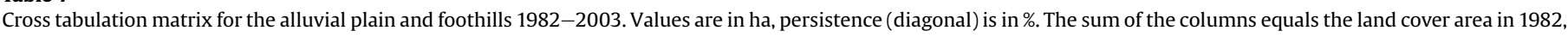
the sum of the rows equals land cover area in 2003.

\begin{tabular}{|c|c|c|c|c|c|c|c|c|c|}
\hline \multirow[t]{2}{*}{ TO 2003} & \multicolumn{9}{|l|}{ FROM 1982} \\
\hline & Forest & Vineyards & Prairies & High & Medium & Low & Other & Total 2003 & Change \\
\hline Forest & $3104.75(87.0)$ & 168.13 & 109.00 & 0.00 & 0.00 & 0.00 & 0.00 & 3381.88 & -186.50 \\
\hline Vineyards & 170.38 & $855.19(62.5)$ & 70.56 & 0.00 & 0.00 & 0.00 & 0.00 & 1096.13 & -272.44 \\
\hline Prairies & 173.44 & 249.75 & 235.50 (49.9) & 0.00 & 0.00 & 0.00 & 0.00 & 658.69 & 186.44 \\
\hline High & 3.44 & 25.19 & 15.50 & $47.75(100.0)$ & 18.31 & 3.63 & 0.00 & 113.81 & 66.06 \\
\hline Medium & 28.50 & 49.38 & 30.06 & 0.00 & $34.75(65.5)$ & 17.19 & 0.00 & 159.88 & 106.81 \\
\hline Low & 32.94 & 20.31 & 11.56 & 0.00 & 0.00 & 39.81 (65.7) & 0.00 & 104.63 & 44.00 \\
\hline Other & 54.94 & 0.63 & 0.06 & 0.00 & 0.00 & 0.00 & $1.81(100.0)$ & 57.44 & 55.63 \\
\hline Total 1982 & 3568.38 & 1368.56 & 472.25 & 47.75 & 53.06 & 60.63 & 1.81 & 5572.44 & 0.00 \\
\hline
\end{tabular}



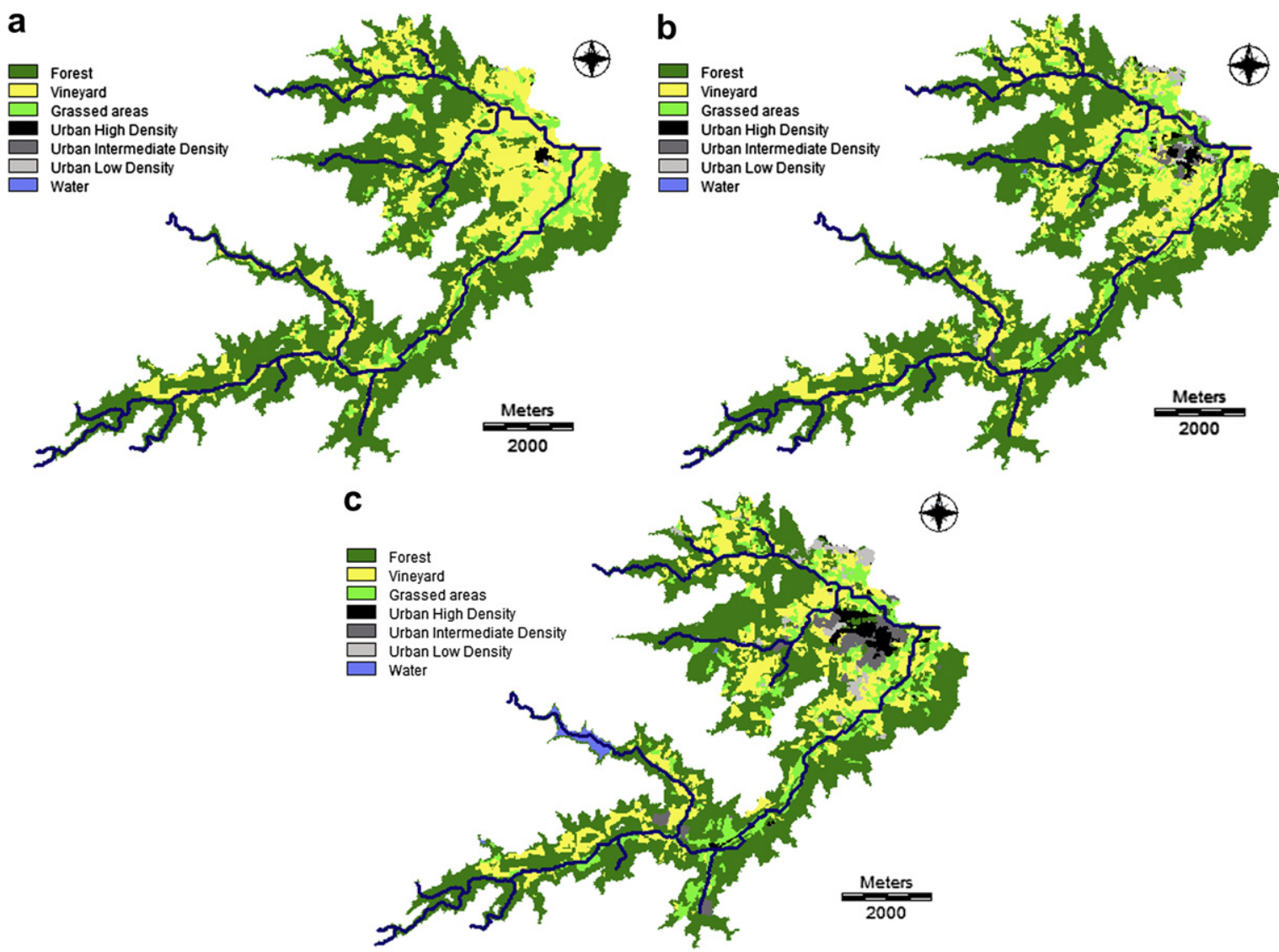

Fig. 5. Land cover maps of alluvial plain and foothills: a) 1950, b)1982, c) 2003.

land cover transitions are concentrated at an altitude $<100 \mathrm{~m}$. In addition, mean slope of the alluvial plain and foothills in 2003 is $14.5 \%$ (median $10.5 \%$ ) whereas it is $46.2 \%$ (median $36.0 \%$ ) for the gauged catchment outside the plain. And within the alluvial plain and foothills, mean slope of the forest is $18.8 \%$ (median 15.9\%) whereas it is only $7.8 \%$ (median $5.6 \%$ ) for the other land covers in

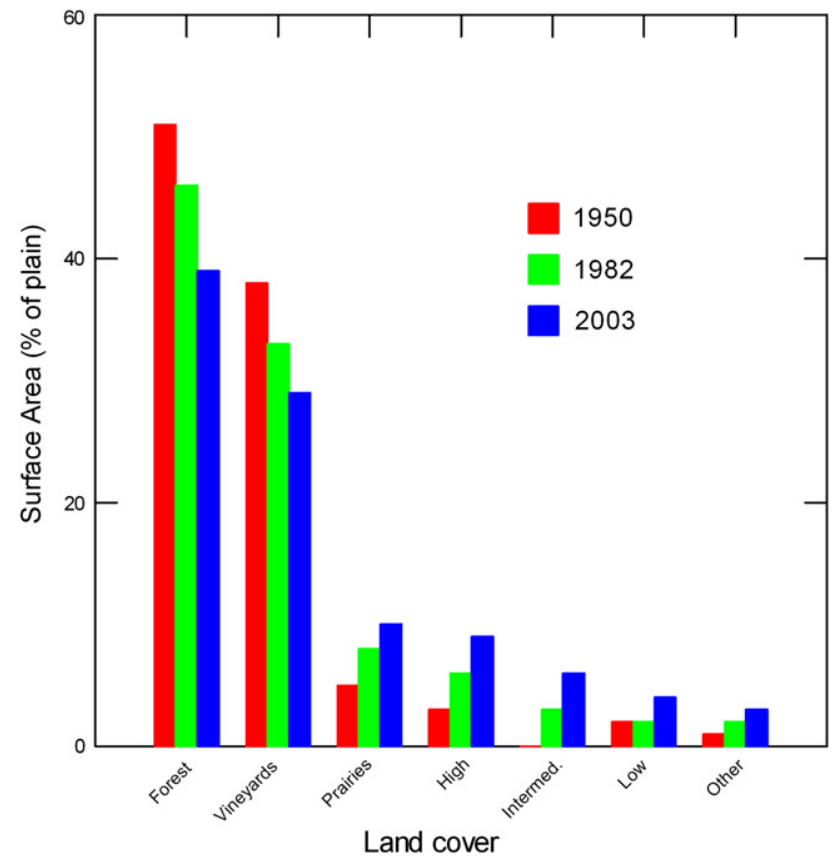

Fig. 6. Summary of land cover changes in alluvial plain and foothills. the same area. There is therefore a clear tendency for forest to occupy steeper slopes in both the gauged catchment as a whole and in the alluvial plain and foothills. In all the Mediterranean land cover change studies cited here (Sluiter and de Jong (2007) Serra et al. (2008); Pelorosso et al. (2009); Geri et al. (2010)), topography played a key role in determining forest cover and land cover change dynamics.

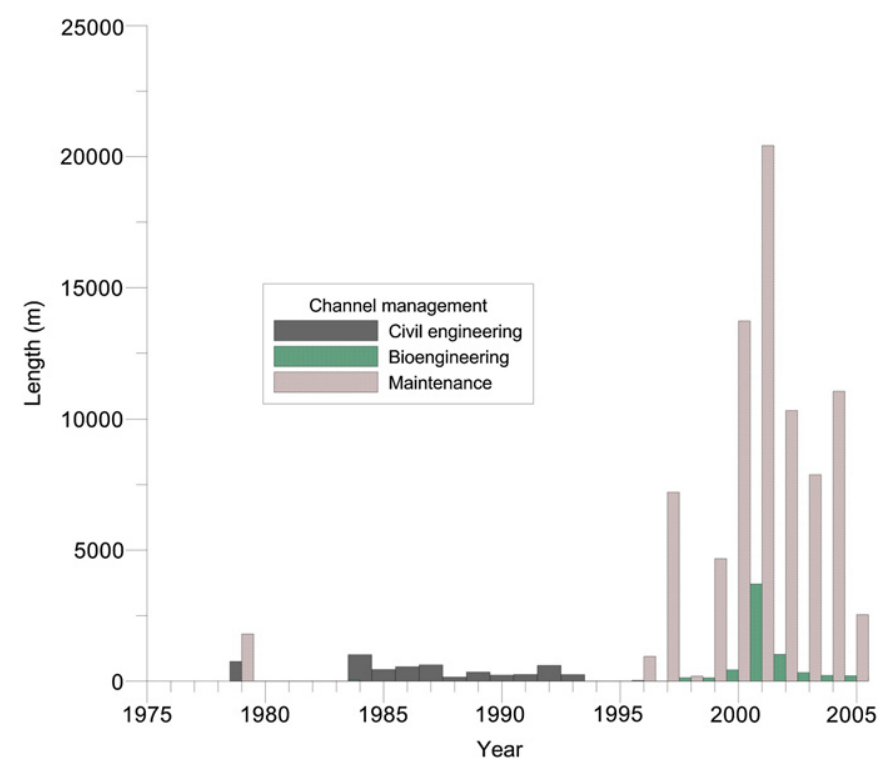

Fig. 7. Linear bank lengths treated with civil engineering, bioengineering, and channel maintenance practises between 1979 and 2005 
Table 8

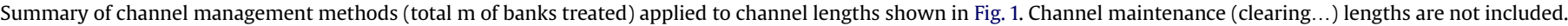

\begin{tabular}{|c|c|c|c|c|c|}
\hline & $\begin{array}{l}\text { (1) Giscle upstream } \\
\text { of Grenouille }\end{array}$ & (2) Grenouille & $\begin{array}{l}\text { (3) Giscle upstream } \\
\text { of Môle }\end{array}$ & (4) Môle & $\begin{array}{l}\text { (5) Giscle downstream } \\
\text { of Môle }\end{array}$ \\
\hline $\begin{array}{l}\text { Civil } \\
\quad \text { engineering (m) }\end{array}$ & 49 & 116 & 1326 & 901 & 243 \\
\hline Bioenginnering (m) & 1570 & 168 & 1167 & 2400 & 108 \\
\hline
\end{tabular}

Land abandonment and forest expansion in hilly areas has been cited as a major land cover change dynamic in a similar Mediterranean context by Geri et al. (2010) in Tuscany. Pelorosso et al. (2009) also noted a strong decline in high altitude agriculture crops in central Italy between 1951 and 2001. However, traditional agricultural abandonment probably occurred earlier in the study catchment since there is no evidence of recent agricultural activities on steep slopes. A 2003 forest fire in the catchment revealed abandoned terraces within the burnt forest, so it is probable that marginal farming activities were abandoned before the 1950's, as was observed by Sluiter and de Jong (2007) in Mediterranean France.

In Serra et al. (2008) and Geri et al. (2010), the lowlands were also the focus of intensive land cover conversion, but in their cases, agriculture expanded at the expense of other covers - meadows and pasture or forest. In this study, both forest and agriculture decreased to the benefit of grassed areas and urban expansion, and forest in the foothills lost to vineyard expansion. These apparent contradictions are related to specific socio-economic conditions absent in the study catchment: agricultural intensification in Serra et al.'s (2008) case was related to the development of an irrigation infrastructure and CAP subsidies for irrigated crops, and in Geri et al's (2010), it was related to local conditions that favoured the expansion and modernisation of an industrialized agriculture economy.

In our case, there is insufficient data to define socio-economic mechanisms, though population growth, secondary housing, and tourism related dynamics are probably important (Van Eetvelde \& Antrop, 2004). The displacement of some vineyards out of the plain and into the foothills is probably related to land value, and some of the vineyards to prairies conversion is related to horseback riding for tourists, though this is only a partial explanation, and the creation of protected natural areas, as in Serra et al. (2008) probably also plays a role near the streams. Distance from the initial village core is important for both vineyards loss and prairies expansion, and distance from the stream network is important for prairies expansion.

The land cover changes experienced in the gauged catchment had no significant impact on runoff. This is in contradiction with most land cover change studies or scenarios which highlight a significant increase in runoff (Ali et al., in press; Burges et al., 1998; Fohrer et al., 2001; Samaniego \& Bardossy, 2006; White \& Greer, 2006). Defining a critical land cover threshold for runoff is complex since the impacts of land cover change depend on the magnitude, type, and spatial location of transitions. In addition, climatic effects can be added to land cover changes making it difficult to sort out transition effects from climate (Sullivan et al., 2004). Burges et al. (1998) compared suburban (30\% impervious) to forested catchments with discharge peaks of $7 \mathrm{~mm} / \mathrm{h}$ vs $0.5 \mathrm{~mm} /$ $\mathrm{h}$ for a large storm (about $90 \mathrm{~mm}$ ). White and Greer (2006) observed an increase in 1 in 2 year flood discharge from $6.41 \mathrm{~m}^{3} \mathrm{~s}^{-1}$ in to $35.67 \mathrm{~m}^{3} \mathrm{~s}^{-1}$ with an increase in urbanisation of from $9 \%$ to $37 \%$ over a 34 year period (1966-2000).

In this case study, forest remained the dominant land cover in the gauged catchment as a whole, changing from $89.3 \%$ to $88.0 \%$ between 1950 and 2003. This is well below the threshold suggested by Bosch and Hewlett (1982, in Fohrer et al., 2004) and Stednick (1996) who state that forest cover changes of less than 10-25\% do not affect annual water yield. In addition, the land cover changes in the alluvial plain and foothills summarized in Fig. 6 show clear compensating effects: loss of pervious forest was compensated by a loss in less pervious vineyards. An increase in impervious urban land covers was compensated by an increase in pervious grassed areas. The overall impact was a negligible impact on storm runoff at the gauge catchment scale. Urbanization has frequently been observed to occur at the expense of agricultural land (Carlson \& Arthur, 2000), but there are few references to the role of green space within urban development (Pauleit et al., 2005). The results of this case study are coherent with the findings of De Roo et al. (2003) who noted that hydrologic impacts of urbanization were neutralized by afforestation.

Although trends are site specific and results cannot be transferred directly to other Mediterranean catchments, since each catchment has its specific land cover and channel management histories, some general remarks can be forwarded. There is a large discrepancy between the modelled impact of land cover change on runoff and the perceived change in risk by local authorities; in the end, it is not that surprising that total runoff changed little given the magnitude of land cover change with respect to total catchment size. Total runoff increased by less than about $2 \%$ over the study period (1950-2003). Assuming an increase of even 10-20\% in peak mean daily discharge (therefore from about $30 \mathrm{~m}^{3} \mathrm{~s}^{-1}$ to about $36 \mathrm{~m}^{3} \mathrm{~s}^{-1}$ at the discharge gauge) to account for changes in peak flows related to improved routing through the stream network, this difference remains relatively small compared to changes in bankfull discharge due to channel management. Channel capacity increased by $50 \%$ to more than $100 \%$ for most of the channels (from about $45.5 \mathrm{~m}^{3} \mathrm{~s}^{-1}$ to $67.5 \mathrm{~m}^{3} \mathrm{~s}^{-1}$ at the gauge). The increase in channel capacity due to river management techniques is probably $5-10$ times greater than the actual increase in runoff due to land cover change. Increased runoff and better river management are invariably linked to urbanisation, and hydrological studies of land cover impacts should take both factors into account, and not only changes in runoff.

Changes in vulnerability within the alluvial plain were not considered and were beyond the scope of this study. It should nonetheless be noted that a probable decrease in flood risk does not indicate a decrease in flood damage in the case of an extreme event. Although not quantified here, if flooding were to occur, the damage costs would be much greater in 2003 than in 1950, despite

Table 9

Estimated channel capacity values $\left(\mathrm{m}^{3} \mathrm{~s}^{-1}\right)$ before 1982 and in 2006 for channel reaches shown in Fig. 1.

\begin{tabular}{llrl}
\hline Location & $\leq 1982$ & 2006 & $\begin{array}{l}\text { Difference } \\
2003-<1982\end{array}$ \\
\hline (1) Giscle upstream of Grenouille & 37.9 & 65.5 & 27.6 \\
(2) Grenouille & 11.1 & 22.0 & 10.9 \\
(3) Giscle upstream of Môle & 23.8 & 105.4 & 81.6 \\
(4) Môle & 38.7 & 39.4 & 0.7 \\
(5) Giscle downstream of Môle & 45.5 & 113.0 & 67.5 \\
\hline
\end{tabular}


a decrease in flood risk. This in itself represents a separate study where coupled hydrologic and hydraulic models would be needed in conjunction with detailed mapping of infrastructures located in the flood plain zone.

\section{Conclusion}

Significant land cover changes occurred in the alluvial plain of the study catchment between 1950 and 2003. In the 1950 to 2003 period, urban areas gained largely from vineyards. These urban development trends were accompanied by a shift from vineyard to grassed areas. The loss in vineyards was partially compensated by the conversion of forested foothills to vineyards between 1982 and 2003. The overall impact of these changes on runoff was small: forest continued to dominate the gauged catchment, and other land cover changes had neutralizing effects on runoff as roughly equal areas increased/decreased in runoff coefficient. The greatest land cover impact on runoff arose from the building of a reservoir in 1991. The presence of the reservoir can decrease runoff by approximately $15 \%$ if the reservoir is filling. It has no impact on runoff if the reservoir is full, as would often be the case for the rainfall event simulated. River management strategies increased bankfull discharge considerably in the channel lengths considered in this study. Therefore, despite a perceived increase in flood risk with urbanisation by local authorities, the actual risk probably decreased as land cover changes integrated compensating green spaces and as channel capacity increased.

\section{References}

Ali M., Khan S.J., Aslam I., \& Khan Z. Simulation of the impacts of land-use change on surface runoff of Lai Nullah Basin in Islamabad, Pakistan. Landscape and Urban Planning. doi: 10.1016/j.landurbplan.2011.05.006, in press.

Arnold, C. L., \& Gibbons, C. J. (1996). Impervious surface Coverage. The Emergence of a key environmental Indicator. Journal of the American Planning Association, 62, 243-258.

Arcement, G. J., \& Schneider, V. R. (1989). Guide for selecting Manning's roughness coefficients for natural channels and flood Plains. U.S. Geological Survey WaterSupply Paper 2339.

Bellot, J., Bonet, A., Sanchez, J. R., \& Chirino, E. (2001). Likely effects of land use changes on the runoff and aquifer recharge in a semiarid landscape using a hydrological model. Landscape and Urban Planning, 55, 41-53.

Blanc, V. (2006). Approche morpho-dynamique historique du bassin versant de la Giscle et de ses affluents. Unpublished Master's dissertation. France: University of Nice Sophia Antipolis.

Bosch, J. M., \& Hewlett, J. D. (1982). A review of catchment experiments to determine the effect of vegetation changes on water yield and evapotranspiration. Journal of Hydrology, 55, 3-23.

Boughton, W. C. (1989). A review of the USDA SCS Curve number method. Australian Journal of Soil Research, 27, 511-523.

Bourrier, R. (2008). Les Réseaux d'Assainissement (5ème édition).. Tec et Doc. 810 pp.

Burges, S. J., Wigmosta, M. S., \& Meena, J. M. (1998). Hydrological effects of land-use change in a Zero-order catchment. Journal of Hydrologic Engineering April, 86-97.

Carlson, T. N., \& Arthur, S. T. (2000). The impact of land use - Land cover changes due to urbanization on surface Microclimate and hydrology: a Satellite Perspective. Global and Planetary Change, 25, 49-65.

Cerdà, A., Imeson, A. C., \& Calvo, A. (1995). Fire and aspect induced differences on the erodibility and hydrology of soils at La Costera, Valencia, southeast Spain. CATENA, 24, 289-304. doi:10.1016/j.rse.2004.11.006.

Chin, A. (2006). Urban transformation of river landscapes in a global context. In. 37th Binghamton geomorphology Symposium - The Human role in changing Fluvial Systems, 79 (pp. 460-487).

Chow, V. T., Maidment, D. R., \& Mays, L. W. (1988). Applied hydrology. USA: McGrawHill. 572 pp.

Cowan, W. L. (1956). Estimating hydraulic roughness coefficients. Agricultural Engineering, 37, 473-475.

Cuo, L., Lettenmaier, D. P., Mattheussen, B. V., Storck, P., \& Wiley, M. (2008). Hydrologic prediction for urban watersheds with the distributed hydrologySoil-Vegetation model. Hydrological Processes, 22, 4205-4213.

De Aranzabal, I., Schmitz, M. F., Aguilera, P., \& Pineda, F. D. (2008). Modelling of landscape changes derived from the dynamics of socio-ecological systems. Ecological Indicators, 8, 672-685. doi:10.1016/j.ecolind.2007.11.003.
De Roo, A., Schmuck, G., Perdigao, V., \& Thielen, J. (2003). The influence of historic land-use changes and Future Planned land-use scenarios on floods in the Oder catchment. Physics and Chemistry of the Earth, Parts $A / B / C, 20,1291-1300$.

Delgado, J., Llorens, P., Nord, G., Calder, I. R., \& Gallart, F. (2009). Modelling the Hydrological Response of a Mediterranean medium-sized headwater basin subject to land cover change: the Cardener River Basin (NE Spain). Journal of Hydrology. doi:10.1016/j.jhydrol.2009.07.024.

Eastman, R. J. (2010). IDRISI Taiga ${ }^{\odot}$ Help System. Worcester MA, USA: Clark Labs, Clark University.

ESRI. (2011). ArcGIS software. http://www.esrifrance.fr/ last consulted 7 July, 2011.

Falcucci, A., Maiorano, L., \& Boitani, L. (2007). Changes in land-use/Land-cover patterns in Italy and their Implications for Biodiversity Conservation. Landscape Ecology, 22, 617-631. doi:10.1007/s10980-006-9056-4.

Fohrer, N., Haverkamp, S., Eckhardt, K., \& Frede, H.-G. (2001). Hydrologic response to land use changes on the catchment scale. Physics and Chemistry of the Earth (B), 26, 577-582.

Fohrer, N., Haverkamp, S., \& Frede, H.-G. (2004). Assessment of the effects of land use patterns on hydrologic landscape functions: development of Sustainable land use Concepts for low Mountain range areas. Hydrological Processes, 18. doi:10.1002/hyp.5623.

Fox, D. M., Bryan, R. B., \& Price, A. G. (1996). The influence of slope angle on infiltration rate and surface Seal characteristics. Geoderma, 80, 181-194 doi:10.1016/S0016-7061(97)00075-X.

Fox, D. M., Maselli, F., \& Carrega, P. (2008). Using SPOT images and field sampling to map burn severity and vegetation factors affecting post forest fire erosion risk CATENA, 75, 326-335. doi:10.1016/j.catena.2008.08.001.

Geri, F., Amici, V., \& Rocchini, D. (2010). Human activity impact on the heterogeneity of a Mediterranean landscape. Applied Geography, 30, 370-379. doi:10.1016 j.apgeog.2009.10.006.

Gregory, K. J. (2006). The human role in changing river channels. In. 37th Binghamton geomorphology Symposium - The Human role in changing Fluvial Systems, 79 (pp. 172-191)

Gregory, K. J., Benito, G., \& Downs, P. W. (2008). Applying fluvial geomorphology to river channel management: background for progress towards a palaeohydrology protocol. The geomorphological and palaeohydrological response of fluvia systems to climatic, human and tectonic controls. Geomorphology, 98, 153-172.

IGN (2003). Institut Géographique National. Ministère du Développement Durable. www.ign.fr (last consulted 7 July, 2011).

Konrad, C. P., \& Booth, D. P. (2002). Hydrologic trends Associated with urban development for selected streams in the Puget Sound Basin, western Washington. U.S. Geological Survey, Water Resources Investigation Report 02-4040.

Li, L., Lu, X., \& Chen, Z. (2007). River channel change during the last 50 years in the middle Yangtze River, the Jianli reach. Monsoon Rivers of Asia, 85, 185-196.

Marques, M. A., \& Mora, E. (1998). Effects on erosion of two post-fire management practices: clear-cutting versus non-intervention. Soil and Tillage Research, 45 , 433-439. doi:10.1016/S0933-3630(97)00039-1.

Mossa, J., \& McLean, M. (1997). Channel planform and land cover changes on a mined river floodplain: Amite River, Louisiana, USA. Applied Geography, 17 43-54.

Mouillot, F., Ratte, J. P., Joffre, R., Mouillot, D., \& Rambal, S. (2005). Long-term forest dynamic after land abandonment in a fire prone Mediterranean landscape (central Corsica, France). Landscape Ecology, 20, 101-112. doi:10.1007/s10980004-1297-5.

Musy, A., \& Higy, C. (2004). Hydrologie - une Science de la Nature. Collection Gérer l'Environnement. Suisse: Presses Polytechniques et Universitaires Romandes. 314 pp.

Nunes, A. N., de Almeida, A. C., \& Coelho, C. O. A. (2011). Impacts of land use and cover type on runoff and soil erosion in a marginal area of Portugal. Applied Geography, 31, 687-699. doi:10.1016/j.apgeog.2010.12.006.

Paul, M. J., \& Meyer, J. L. (2001). Streams in the urban Lanscape. Annual Review of Ecology and Systematics, 32, 333-365.

Pauleit, S., Ennos, R., \& Golding, Y. (2005). Modeling the environmental impacts of urban land use and land cover change - a study in Merseyside, UK. Landscape and Urban Planning, 71, 295-310. doi:10.1016/j.landurbplan.2004.03.009.

Pauleit, S., \& Duhme, F. (2000). Assessing the environmental performance of land cover types for urban planning. Landscape and Urban Planning, 52, 1-20.

Pausas, J. G., \& Vallejo, V. R. (1999). The role of fire in European Mediterranean Ecosystems. pp. 3-16.

Pelorosso, R., Leone, A., \& Boccia, L. (2009). Land cover and land use change in the Italian central Apennines: a comparison of assessment methods. Applied Geography, 29, 35-48. doi:10.1016/j.apgeog.2008.07.003.

Perrin, C., Michel, C., \& Andréassian, V. (2003). Improvement of a parsimonious model for streamflow simulation. Journal of Hydrology, 279, 275-289.

Pontius, R. G., Shusas, E., \& McEachern, M. (2004). Detecting important categorical land changes while accounting for persistence. Agriculture, Ecosystems and Environment, 101, 251-268. doi:10.1016/j.agee.2003.09.008.

Riedel, M. S., Verry, E. S., \& Brooks, K. N. (2005). Impacts of Land Use Conversion on Bank Full Discharge and Mass Wasting. Journal of Environmental Management 76, 326-337.

Roche, M. (1963). Hydrologie de Surface. Paris: Gauthier-Villars. 431 pp.

Roche, M. (1967). Recherche d'un Hydrogramme Standard. Paris: Cahiers ORSTOM. 18 pp. IV.

Samaniego, L., \& Bardossy, A. (2006). Simulation of the impacts of land use/cover and climatic changes on the runoff characteristics at the mesoscale. Ecological Modelling, 196, 45-61. doi:10.1016/j.ecolmodel.2006.01.005. 
Schueler, T. (1994). The Importance of imperviousness. Watershed Protection Techniques, $1,100-111$.

Serra, P., Pons, X., \& Sauri, D. (2008). Land-cover and land-use change in a Mediterranean landscape: a spatial analysis of driving forces integrating biophysical and human factors. Applied Geography, 28, 189-209. doi:10.1016 j.apgeog.2008.02.001.

Sluiter, R., \& de Jong, S. M. (2007). Spatial patterns of Mediterranean land abandonment and related land cover transitions. Landscape Ecology, 22, 559-576. doi:10.1007/s10980-006-9049-3.

Stednick, J. D. (1996). Monitoring the effects of timber harvest on annual water yield. Journal of Hydrology, 176, 79-95.

Sullivan, A., Ternan, J. L., \& Williams, A. G. (2004). Land use change and hydrological response in the Camel catchment, Cornwall. Applied Geography, 24, 119-137. doi:10.1016/j.apgeog.2003.11.002.
Sumner, M. E., \& Stewart, B. A. (1992). In Soil Crusting (Ed.), Chemical and Physical processes (Advances in soil Science). Florida: Lucas Publishers.

Surian, N., \& Rinaldi, M. (2003). Morphological Response to River Engineering and Management in Alluvial Channels in Italy. Geomorphology, 50, 307-326.

Van Eetvelde, V., \& Antrop, M. (2004). Analyzing structural and functional changes of traditional landscapes - two examples from Southern France. Landscape and Urban Planning, 67, 79-95. doi:10.1016/S0169-2046(03)00030-6.

White, M. D., \& Greer, K. A. (2006). The effects of watershed urbanization on the stream hydrology and riparian vegetation of Los Peñasquitos Creek, California. Landscape and Urban Planning, 74, 125-138. doi:10.1016/ j.landurbplan.2004.11.015.

Wu, W., Hall, C. A. S., \& Scatena, F. N. (2007). Modelling the impact of recent landcover changes on the stream flows in northeastern Puerto Rico. Hydrological Processes, 21, 2944-2956. 